\title{
Los dos hermanos y el salmón más grande
}

\section{Yulissa Naranjo}

Había una vez en una montaña en el sur del bosque, una familia de osos. Consistía de mamá oso, papá oso y sus dos hijos. El hijo mayor era el mejor cazador de toda la familia. El hermano menor era el peor, los peces siempre se deslizaban de su agarre. Por esta razón, el hermano menor se puso nervioso cuando se dio cuenta de que su mamá, para sucumpleaños, quería el salmón más grande.

El hermano mayor se fue corriendo hacia el río cantando que encontraría el pescado más grande para regalarle a su mamá. El hermano menor, sin ánimo, fue caminando en la dirección de su hermano.

¿Cómo voy a lograr regalarle a mi madre el pescado de sus sueños? - pensaba el oso menor. Llegó al rio y encontró a su hermano con el salmón más grande que jamás había visto en su vida.

"Ya encontré el pescado más grande del mundo. Es mejor que busques otro regalo para mamá. Tú no puedes hacer lo que yo hice" - dijo el hermano mayor.

"¡Pero yo también quiero darle el pescado más delicioso a nuestra madre!” El hermano menor corrió hacia el río, intento cazar un pescado pero cogió uno tan pequeño que se le cayó de su garras grandes.

El hermano mayor dejó salir la risa más grande de su vida. Tan fuerte fue la risa que soltó el salmon y éste cayó de nuevo al rio. El salmón comenzó a nadar hacia el hermano menor y él vio su oportunidad para cazarlo. Metió su cabeza debajo el agua y usó sus dientes para agarrar el pescado. Sacó su cabeza del agua y alzó sus garras en el aire: ¡fue un éxito!

Los dos hermanos llegaron a casa y el hermano mayor le dio a su mamá un salmón grande. La mamá le dio un beso y se comió el pescado. El hermano menor le dio su pescado y su mamá quedó asombrada.

"iQué pescado tan grande me trajiste! No creo que me lo pueda comer todo sola. Vamos todos a comer este salmón juntos".

Todos se reunieron alrededor del pez y comieron.

\section{Moraleja}

"Nunca pienses menos de ti mismo si alguien dijo que lo eres". 